\title{
PENGARUH KETERAMPILAN MEMBUKA PELAJARAN TERHADAP MOTIVASI SISWA DALAM BELAJAR BAHASA INDONESIA SEKOLAH DASAR
}

Keyword: Opening Learning Skill, Student Motivation

\begin{abstract}
ABSTRAK
Penelitian ini bertujuan untuk: 1) Mengetahui kemampuan guru dalam pembelajaran Bahasa Indonesia dengan keterampilan membuka pelajaran, 2) Mengetahui aktivitas siswa dalam mengikuti pembelajaran dengan menggunakan keterampilan membuka pelajaran, 3) Mengetahui gambaran motivasi siswa dalam pembelajaran Bahasa Indonesia sebelum dan sesudah diberi keterampilan membuka pelajaran pada kelompok eksperimen, 4) Mengetahui gambaran motivasi belajar siswa dalam pembelajaran Bahasa Indonesia sebelum dan sesudah diberi pembelajaran tanpa kegiatan membuka pelajaran, 5) Mengetahui pengaruh keterampilan membuka pelajaran terhadap motivasi belajar siswa dalam pembelajaran Bahasa Indonesia. Jenis penelitian ini adalah true experiment dengan desain penelitian Pre-Test Post-Test Control Group Design. Populasi penelitian ini siswa kelas V SDN Inpres 139 Lambatorang Kecamatan Bantimurung Kabupaten Maros. Sampel yang digunakan penelitian ini adalah 30 siswa yang terdiri dari 15 siswa kelas Va dan 15 siswa kelas Vb. Data yang diperoleh dianalisis dengan statistik deskriktif dan statistic inferensial. Hasil penelitian menunjukkan 1) kemampuan guru dalam pembelajaran Bahasa Indonesia dengan keterampilan membuka pelajaran mengalami peningkatan, 2) aktivitas siswa dalam pembelajaran Bahasa Indonesia dengan keterampilan membuka pelajaran mengalami peningkatan 3) motivasi belajar siswa yang diajar dengan keterampilan membuka pelajaran mengalami peningkatan, 4) motivasi belajar siswa yang diajar tanpa keterampilan membuka pelajaran tidak mengalami peningkatan, dan 5) keterampilan membuka pelajaran berpengaruh terhadap motivasi belajar siswa dalam pembelajaran Bahasa Indonesia.
\end{abstract}

Kata kunci: Keterampilan Membuka Pelajaran, Motivasi Belajar 


\section{PENDAHULUAN}

Keterampilan membuka pelajaran adalah kegiatan yang dilakukan oleh guru dalam kegiatan pembelajaran untuk menciptakan prakondisi peserta didik agar minat dan perhatiannya terpusat pada apa yang akan dipelajarinya. Kegiatan membuka pelajaran dilakukan pada awal proses pembelajaran. Pada saat ini tenaga pendidik mengemukakan tujuan yang akan dicapai, menarik perhatian peserta didik, memberi acuan, dan membuat kaitan antara materi yang telah dikuasai oleh peserta didik dengan bahan yang akan dipelajarinya. Guru dikatakan telah membuka pelajaran apabila telah berhasil membuka konflik psikis pada diri siswa siswa. Pembelajaran merupakan suatu proses interaksi antara pendidik dan peserta didik. Guru merupakan komponen terpenting dalam proses pembelajaran, karena guru berhubungan langsung dengan siswa sebagai subjek dan objek belajar.

Motivasi belajar sangatlah berperan penting dalam kesuksesan belajar sebab tanpa adanya motivasi yang melekat dibenak akan sulit mewujudkan segala tindakan ke arah lebih baik. Menurut Clayton Alderfer (Nashar, 2004: 42) "motivasi belajar adalah kecenderungan siswa dalam melakukan kegiatan belajar yang didorong oleh hasrat untuk mencapai prestasi atau hasil belajar sebaik mungkin". Nevid (2013: 23) mengemukakan "the term motivation refers to factors that activate, direct, and sustain goaldirected behavior". Pernyataan tersebut mengungkapkan bahwa motivasi merujuk pada faktor-faktor yang mengaktifkan, langsung, dan mempertahankan perilaku yang ingin dicapai. Motivasi berpengaruh pada aktivitas belajar siswa. Siswa yang memiliki motivasi belajar akan lebih bersemangat mengikuti pembelajaran yang tentunya akan memberi pengaruh positif terhadap hasil belajarnya.

Abimanyu (2008) mengemukakan bahwa siswa yang diajar dengan ketermpilan membuka pelajaran memiliki hasil belajar yang tinggi karena siswa lebih termotivasi mengikuti pelajaran. Sebaliknya pembelajaran tanpa keterampilan membuka pelajaran tidak membangkitkan motivasi belaja siswa sebagaimana yang terlihat pada observasi awal yang dilakukan tanggal 24 Februari 2016 di SDN 139 Inpres Lambatorang Kecamatan Bantimurung Kabupaten Maros tampak bahwa guru kelas $\mathrm{V}$ mengajar tanpa memperhatikan aspek-aspek keterampilan mengajar termasuk tidak melakukan keterampilan membuka pelajaran sehingga siswa kurang memiliki kesiapan dalam belajar. Guru tidak menimbulkan motivasi siswa serta tidak memberi acuan bagaimana jalannya proses pembelajaran yang akan dilakukan sehingga siswa cenderung pasif tanpa ada keinginan untuk berpartisipasi dalam pembelajaran. Siswa mendengar penjelasan guru lalu mengerjakan tugas yang diberikan, bahkan terkadang siswa memperhatikan hal lain yang tidak ada hubungannya dengan pembelajaran. Siswa kurang aktif dalam mengerjakan tugastugas yang diberikan. Hal ini menunjukkan rendahnya motivasi belajar siswa.

Rusman (2011) mengemukakan keterampilan mengajar merupakan suatu karakteristik umum dari seseorang yang berhubungan dengan pengetahuan dan keterampilan yang diwujudkan melalui tindakan. Keterampilan dasar mengajar pada dasarnya adalah berupa bentuk perilaku yang bersifat mendasar dan khusus yang harus dimiliki oleh seorang guru sebagai modal awal untuk melaksanakan tugas-tugas pembelajarannya secara terencana dan profesional dalam mengajar merupakan salah satu jenis keterampilan yang harus dikuasai oleh guru.

Sardiman (2007: 47) menyatakan "mengajar pada dasarnya merupakan suatu usaha untuk menciptakan kondisi atau sistem lingkungan yang mendukung dan memungkinkan untuk berlangsungnya proses belajar". Menurut Usman (2008: 6) "mengajar pada prinsipnya membimbing siswa dalam kegiatan belajarmengajar atau mengandung pengertian bahwa mengajar merupakan suatu usaha mengorganisasi lingkungan dalam hubungannya dengan anak didik dan bahan pengajaran yang menimbulkan proses belajar".

Abimanyu (2008: 2) mengemukakan bahwa keterampilan dasar mengajar terdiri dari: Keterampilan bertanya (dasar, lanjut), keterampilan memberi penguatan, keterampilan mengadakan variasi, keterampilan menjelaskan, keterampilan membuka dan menutup pelajaran, keterampilan memimpin diskusi kelompok kecil, keterampilan mengelola kelas, dan keterampilan mengajar kelompok kecil dan perorangan.

Salah satu bentuk keterampilan mengajar adalah keterampilan membuka pelajaran. Keterampilan membuka pelajaran adalah 
kegiatan yang dilakukan oleh guru untuk menciptakan situasi siap mental dan menimbulkan siswa agar terpusat perhatiannya pada hal-hal yang dipelajari. Kegiatan membuka pelajaran semacam itu tidak saja harus dilakukan guru pada awal jam pelajaran, tetapi juga pada awal setiap penggal kegiatan dari inti pelajaran yang diberikan selama jam pelajaran itu, dengan kegiatan yang lebih sederhana. Abimanyu (2008: 55) mengemukakan bahwa "membuka pelajaran adalah kegiatan yang dilakukan oleh guru untuk menciptakan suasana siap mental dan menimbulkan perhatian siswa agar terpusat pada hal-hal yang akan dipelajari”. Sementara Djamarah (2005: 114) berpendapat bahwa "keterampilan membuka pelajaran adalah perbuatan guru untuk menciptakan siap mental dan menimbulkan perhatian anak didik agar berpusat pada apa yang akan dipelajari".

Majid (2010: 64) menjelaskan "membuka pelajaran adalah usaha yang dilakukan oleh guru dalam kegiatan pembelajaran untuk menciptakan pra kondisi bagi siswa agar mental maupun perhatian terpusat pada pengalaman belajar yang disajikan sehingga akan mudah mencapai kompetensi yang diharapkan". Senada dengan pendapat tersebut, Rusman (2011: 53) mengemukakan bahwa "membuka pelajaran ialah usaha atau kegiatan yang dilakukan oleh guru dalam kegiatan belajar mengajar agar mental maupun perhatian peserta didik terpusat pada apa yang akan dipelajarinya sehingga usaha tersebut akan memberikan efek yang positif terhadap kegiatan belajar".

Sebagaimana keterampilan mengajar lainnya, ada prinsip-prinsip yang mendasari penggunaan komponen keterampilan membuka pelajaran yang harus dipertimbangkan oleh guru seperti yang disebutkan oleh Abimanyu (2008: 57) yaitu :1) Bermakna. Dalam usaha menarik perhatian atau memotivasi siswa guru hendaknya memilih cara yang relevan dengan isi dan tujuan pelajaran. Cara atau usaha yang sifatnya dicaricari atau dibuat-buat hendaknya dihindarkan. Cerita singkat atau lawakan yang tidak ada hubungannya dengan pelajaran mungkin sementara bisa memikat siswa tetapi akan gagal dalam mewujudkan kelangsungan penguasaan pelajaran, dan 2) Berkesinambungan. Aktivitas yang ditempuh oleh guru dalam memperkenalkan dan merangkum kembali pokok-pokok penting pelajaran hendaknya merupakan bagian dari kesatuan yang utuh.
Dalam mewujudkan prinsip berurutan dan berkesinambungan ini perlu diusahakan suatu susunan yang tepat, berhubungan dengan minat siswa, ada kaitannya yang jelas antara satu bagian dengan bagian lainnya, atau ada kaitannya dengan pengalaman dan pengetahuan yang telah dimiliki siswa.

Abimanyu (2008: 57) menyebutkan bahwa komponen-komponen pelajaran itu meliputi "apersepsi, menarik perhatian siswa, menimbulkan motivasi, memberi acuan, dan membuat kaitan". Tiap komponen terdiri atas beberapa kelompok aspek kegiatan yang saling berhubungan. Sebagai keterampilan maka sifatnya integratif dan ada beberapa komponen yang tumpang tindih. Disamping itu, membuka pelajaran harus sesuai dengan hakikat meteri pelajaran, tujuan pelajaran dan siswa. Karena itu, mungkin saja hanya beberapa komponen keterampilan saja yang dipakai, misalnya: apersepsi, membuat kaitan, dan memberi acuan. Komponen-komponen dan aspek- aspek membuka pelajaran tersebut menurut Abimanyu (2008) adalah: 1) Apersepsi yakni usaha guru untuk mengingatkan kembali pelajaran yang lalu dengan tujuan agar siswa makin menguasai materi pelajaran itu dan agar kaitan antara pelajaran yang lalu dengan pelajaran yang akan diajarkannya. Usaha guru umumnya berupa pertanyaan tentang isi materi pelajaran yang telah diajarkan sebelumnya, 2) Menarik perhatian siswa yakni banyak cara dapat digunakan guru untuk menarik perhatian siswa, 3) Menimbulkan Motivasi. Salah satu tujuan dari prosedur membuka pelajaran adalah memilih secara hati-hati hal-hal yang menjadi perhatian siswa. Hal-hal yang menjadi perhatian siswa itu hendaknya dapat digunakan untuk menimbulkan motivasi, 4) Memberi acuan (structuring). Dalam hubunganya dengan membuka pelajaran, memberi acuan diartikan sebagai usaha mengemukakan secara spesifik dan singkat serangkaian alternatif yang memungkinkan siswa memperoleh gambaran yang jelas mengenai halhal yang akan dipelajari dan cara yang hendak ditempuh dalam mempelajari materi pelajaran dan 5) Membuat kaitan. Jika guru akan mengajarkan materi pelajaran yang baru perlu kiranya ia menghubungkannya dengan hal-hal yang telah dikenal siswa atau dengan pengalaman-pengalaman siswa terdahulu atau dengan minat dan kebutuhan-kebutuhannya untuk mempermudah pemahaman. Hal-hal yang 
telah dikenal, pengalaman-pengalaman, minat, dan kebutuhan-kebutuhan siswa itulah yang disebut bahan pengait.

Donald (Sardiman, 2007: 73) mengemukakan "motivasi adalah perubahan energi dalam diri seseorang yang ditandai dengan munculnya "felling" dan didahului dengan tanggapan terhadap adanya tujuan". Menurut Robbin (Khairani, 2014: 176) "motivasi adalah kemauan untuk mengerjakan sesuatu". Selanjutnya menurut Greenberg dan Baron (Khairani, 2014: 176) "motivasi adalah suatu proses yang mendorong, mengarahkan, dan memelihara perilaku manusia ke arah pencapaian tujuan dan segala yang ada di dalam diri manusia untuk membentuk motivasi".

Hadis dan Nurhayati (2014: 29) mengungkapkan bahwa motivasi mengandung tiga elemen penting, yaitu "motivasi itu mengawali terjadinya perubahan energi pada diri setiap individu manusia, motivasi ditandai dengan munculnya perasaan afeksi seseorang dan motivasi akan diransang karena adanya tujuan". Dengan mengetahui pengertian motif atau motivasi secara umum, maka pengertian motivasi belajar ialah kekuatan yang timbul dari dalam diri individu yang mendorong individu melakukan aktifitas belajar.

Keterampilan membuka pelajaran sangat penting untuk diterapkan oleh guru karena awal pembelajaran dapat memberi arah bagaimana keseluruhan proses pembelajaran berlangsung. Pelajaran yang dibuka dengan baik dapat menarik perhatian siswa. Kegiatan pembelajaran yang diawali dengan apersepsi membantu siswa melihat keterkaitan antar materi yang telah dan akan dipelajari. Guru dapat mengemukakan halhal atau ide yang menimbulkan rasa ingin tahu siswa sehingga siswa tertarik mengikuti pelajaran. Siswa yang memiliki ketertarikan akan termotivasi dalam mengikuti proses pembelajaran. Dengan kata lain, keterampilan membuka pelajaran berdampak pada motivasi siswa mengikuti pelajaran. Oleh karena itu, peneliti akan melakukan penelitian untuk melihat pengaruh keterampilan membuka pelajaran terhadap motivasi siswa dalam belajar Bahasa Indonesia siswa SDN 139 Inpres Lambatorang Kecamatan Bantimurung Kabupaten Maros.

Penelitian ini bertujuan: 1) Untuk mengetahui kemampuan guru dalam pembelajaran Bahasa Indonesia dengan keterampilan membuka pelajaran, 2) untuk mengetahui aktivitas siswa dalam mengikuti pembelajaran dengan menggunakan keterampilan membuka pelajaran, 3) Untuk mengetahui gambaran motivasi siswa dalam pembelajaran Bahasa Indonesia sebelum dan sesudah diberi keterampilan membuka pelajaran pada kelompok eksperimen, 4) Untuk mengetahui gambaran motivasi belajar siswa dalam pembelajaran Bahasa Indonesia sebelum dan sesudah diberi pembelajaran tanpa kegiatan membuka pelajaran, 5) mengetahui pengaruh keterampilan membuka pelajaran terhadap motivasi belajar siswa dalam pembelajaran Bahasa Indonesia.

Hipotesis penelitian ini adalah ada pengaruh keterampilan membuka pelajaran terhadap motivasi belajar siswa dalam pembelajaran Bahasa Indonesia siswa SDN 139 Inpres Lambatorang Kecamatan Bantimurung Kabupaten Maros dimana siswa yang diajar dengan memakai keterampilan membuka pelajaran motivasi belajarnya lebih tinggi.

\section{METODE PENELITIAN}

Jenis penelitian yang digunakan adalah true experiment (eksperimen sebenarnya). Desain yang digunakan adalah Pre-Test PostTest Control Group Design. Variabel dalam penelitian ini yaitu keterampilan membuka pelajaran sebagai variabel bebas (X) dan motivasi belajar siswa sebagai variabel terikat (Y).

Variabel penelitian perlu didefenisikan secara operasional untuk menghindari perbedaan penafsiran menyangkut variabel dalam penelitian ini. 1) Keterampilan membuka pelajaran adalah kemampuan guru dalam mengawali pembelajaran dengan melakukan a) apersepsi dengan menanyakan materi pelajaran yang lalu, b) menimbulkan motivasi dengan menumbuhkan rasa ingin tahu atau mengemukakan ide yang bertentangan, c) memberi acuan dengan mengemukakan tujuan pembelajaran dan batasbatas tugas atau langkah-langkah pembelajaran yang akan dilakukan, dan 2) Motivasi belajar siswa adalah dorongan belajar pada diri siswa yang meliputi tekun menghadapi tugas, ulet menghadapi kesulitan, menunjukkan minat terhadap bermacam-macam masalah belajar, lebih senang bekerja mandiri, tidak cepat bosan dengan tugas-tugas rutin, dapat mempertahankan pendapatnya, tidak mudah melepaskan apa yang diyakini, senang mencari dan memecahkan masalah. 
Populasi dalam penelitian ini adalah siswa kelas V Inpres 139 Lambatorang Kecamatan Bantimurung Kabupaten Maros. Adapun jumlah siswa kelas V pada tahun ajaran 2015/2016 adalah sejumlah 49 siswa yang terdiri dari 25 siswa kelas Va dan 24 siswa kelas Vb.

Sampel yang digunakan dalam penelitian ini adalah 30 siswa yakni 15 siswa kelas Va dan 15 siswa kelas Vb. Pengambilan sampel dilakukan dengan menggunakan teknik simple random sampling. Penentuan kelompok eksperimen dan kelompok kontrol dilakukan dengan mengundi dan hasilnya kelas Va sebagai kelompok eksperimen dan kelas $\mathrm{Vb}$ sebagai kelompok kontrol.

Pengumpulan data dalam penelitian ini dilakukan dengan menggunakan observasi dan angket. Sebelum angket digunakan, terlebih dulu dilakukan analisis terhadap instrumen soal melalui uji validitas dan uji realibilitas. Validitas konstruk divalidasi oleh ahli dan selanjutnya diujicoba lapangan. Uji coba dilakukan pada 11 siswa kelas V SD 225 Inpres Panaikang Kecamatan Bantimurung Kabupaten Maros. Validitas butir soal diukur dengan menggunakan korelasi product moment. Hasil uji validasi yaitu terdapat 9 item angket yang tidak valid sehingga jumlah item angket yang akan digunakan adalah 31 item. Uji reliabilitas dilakukan dengan testretest dan diperoleh hasil bahwa instrumen yang digunakan reliabel.
Analisis data dilakukan secara deskriptif dan inferensial. Analisis deskriptif dilakukan untuk memperoleh gambaran pelaksanaan keterampilan membuka pelajaran. Analisis inferensial dilakukan untuk mengetahui pengaruh keterampilan membuka pelajaran terhadap motivasi belajar siswa dalam pembelajaran Bahasa Indonesia siswa SDN 139 Inpres Lambatorang Kecamatan Bantimurung Kabupaten Maros. Sebelum dianalisis secara inferensial terlebih dulu dilakukan uji normalitas dan uji homogenitas. Hasil yang diperoleh menunjukkan bahwa data berdistribusi normal dan berasal dari varian yang sama. Setelah itu dilakukan analisis inferensial dengan menggunakan uji t.

\section{HASIL DAN PEMBAHASAN}

\section{Hasil}

1. Gambaran kemampuan guru dalam pembelajaran Bahasa Indonesia dengan keterampilan membuka pelajaran di SDN 139 Inpres Lambatorang

Observasi dilakukan terhadap aktivitas guru dalam melaksanakan keterampilan membuka pelajaran dalam pembelajaran Bahasa Indonesia. Hasil observasi dapat dilihat pada Tabel 4.1 berikut:

Tabel 4.1 Hasil Observasi Aktivitas Guru dalam Pelaksanaan Keterampilan Membuka Pelajaran

\begin{tabular}{ccccccc}
\hline \multirow{2}{*}{ Skala } & \multicolumn{5}{c}{ Pertemuan ke- } & \multirow{2}{*}{ Kategori } \\
\cline { 2 - 6 } & $\mathbf{1}$ & $\mathbf{2}$ & $\mathbf{3}$ & $\mathbf{4}$ & $\mathbf{5}$ & \\
\hline $81 \%-100 \%$ & & & 83,3 & 100 & 100 & Sangat Tinggi \\
$61 \%-80 \%$ & 66,7 & 66,7 & & & & Tinggi \\
$41 \%-60 \%$ & & & & & & Cukup \\
$21 \%-40 \%$ & & & & & & Rendah \\
$0-20 \%$ & & & & & & Sangat Rendah \\
\hline
\end{tabular}

Berdasarkan Tabel 4.1 dapat dilihat bahwa pada pertemuan pertama dan kedua aktivitas guru berada pada kategori tinggi. Pada pertemuan ketiga, keempat dan kelima aktivitas guru berada pada kategori sangat tinggi.

2. Gambaran aktivitas siswa dalam mengikuti pembelajaran Bahasa Indonesia dengan

Tabel 4.2 Hasil Observasi Aktivitas Siswa dalam Pelaksanaan Keterampilan Membuka Pelajaran menggunakan keterampilan membuka pelajaran di SDN 139 Inpres Lambatorang

Observasi dilakukan terhadap aktivitas siswa dalam melaksanakan keterampilan membuka pelajaran dalam pembelajaran Bahasa Indonesia. Hasil observasi dapat dilihat pada Tabel 4.2 berikut: 


\begin{tabular}{ccccccc}
\hline \multirow{2}{*}{ Skala } & \multicolumn{5}{c}{ Pertemuan ke- } & \multirow{2}{*}{ Kategori } \\
\cline { 2 - 6 } & $\mathbf{1}$ & $\mathbf{2}$ & $\mathbf{3}$ & $\mathbf{4}$ & $\mathbf{5}$ & \\
\hline $81 \%-100 \%$ & & & 83,3 & 100 & 100 & Sangat Tinggi \\
$61 \%-80 \%$ & & 66,7 & & & & Tinggi \\
$41 \%-60 \%$ & 50 & & & & & Cukup \\
$21 \%-40 \%$ & & & & & & Rendah \\
$0-20 \%$ & & & & & & Sangat Rendah \\
\hline
\end{tabular}

Berdasarkan Tabel 4.2 dapat dilihat bahwa pada pertemuan pertama aktivitas siswa berada pada kategori cukup. Pada pertemuan kedua aktivitas siswa berada pada kategori tinggi, pada pertemuan ketiga, keempat dan kelima aktivitas siswa berada pada kategori sangat tinggi.

3. Gambaran motivasi siswa dalam pembelajaran Bahasa Indonesia di SDN 139
Inpres Lambatorang sebelum dan sesudah diberi keterampilan membuka pelajaran

Data motivasi belajar siswa pada pretest dan posttest dianalisis untuk megetahui motivasi siswa sebelum dan sesudah pembelajaran dengan keterampilan membuka pelajaran. Data motivasi belajar siswa kelompok eksperimen dapat dilihat pada tabel 4.3 berikut:

Tabel 4.3 Data Motivasi Belajar Siswa Kelompok Eksperimen pada Pretest dan Posttest

\begin{tabular}{ccccccc}
\hline \multirow{2}{*}{ No } & \multirow{2}{*}{ Skala } & \multicolumn{2}{c}{ Pre Test } & \multicolumn{2}{c}{ Post Test } & \multirow{2}{*}{ Kategori } \\
\cline { 2 - 6 } & & $\mathbf{F}$ & $\mathbf{\%}$ & $\mathbf{F}$ & $\mathbf{\%}$ & \\
\hline 1. & $132-155$ & 0 & 0 & 14 & $93,3 \%$ & Sangat Tinggi \\
2. & $108-131$ & 0 & 0 & 1 & $6,7 \%$ & Tinggi \\
3. & $84-107$ & 12 & $80 \%$ & 0 & 0 & Cukup \\
4. & $60-83$ & 3 & $20 \%$ & 0 & 0 & Rendah \\
5. & $31-59$ & 0 & 0 & 0 & 0 & Sangat Rendah \\
\hline & Jumlah & 15 & $100 \%$ & 15 & $100 \%$ & \\
\hline
\end{tabular}

Berdasarkan tabel 4.3 dapat dilihat bahwa motivasi belajar kelompok eksperimen menunjukkan peningkatan yang signifikan setelah proses pembelajaran dengan keterampilan membuka pelajaran. Hasil pretest menunjukkan bahwa dari 15 siswa, 12 siswa $(80 \%)$ berada dalam kategori cukup dan 3 siswa (20\%) berada dalam kategori rendah. Tidak ada siswa yang berada pada kategori tinggi atau sangat tinggi. Hasil posttest menunjukkan peningkatan motivasi belajar siswa. Dari 15 siswa, 14 siswa $(93,3 \%)$ berada dalam kategori sangat tinggi dan 1 siswa $(6,7 \%)$ berada dalam kategori tinggi. Hasil tersebut menunjukkan bahwa terjadi peningkatan motivasi belajar pada kelompok eksperimen yang proses pembelajarannya menggunakan keterampilan membuka pelajaran.

4. Gambaran motivasi siswa dalam pembelajaran Bahasa Indonesia di SDN 139 Inpres Lambatorang sebelum dan sesudah diberi pembelajaran tanpa kegiatan membuka pelajaran

Data motivasi belajar siswa pada pretest dan posttest dianalisis untuk megetahui motivasi siswa sebelum dan sesudah pembelajaran. Data motivasi belajar siswa kelompok kontrol dapat dilihat pada tabel 4.4 berikut:

Tabel 4.4 Data Motivasi Belajar Siswa Kelompok Kontrol pada Pretest dan Posttest

\begin{tabular}{|c|c|c|c|c|c|c|}
\hline \multirow{2}{*}{ No } & \multirow{2}{*}{ Skala } & \multicolumn{2}{|c|}{ Pre Test } & \multicolumn{2}{|c|}{ Post Test } & \multirow{2}{*}{ Kategori } \\
\hline & & $\mathbf{F}$ & $\%$ & $\mathbf{F}$ & $\%$ & \\
\hline 1. & $132-155$ & 0 & 0 & 0 & 0 & Sangat Tinggi \\
\hline 2. & $108-131$ & 0 & 0 & 0 & 0 & Tinggi \\
\hline 3. & $84-107$ & 13 & $86,7 \%$ & 13 & $86,7 \%$ & Cukup \\
\hline 4. & $60-83$ & 2 & $13,3 \%$ & 2 & $13,3 \%$ & Rendah \\
\hline
\end{tabular}




\begin{tabular}{rcccccc}
5. & $31-59$ & 0 & 0 & 0 & 0 & Sangat Rendah \\
\hline Jumlah & 15 & $100 \%$ & 15 & $100 \%$ & \\
\hline
\end{tabular}

Sumber: diolah dari hasil penelitian (lampiran 11)

Berdasarkan tabel 4.4 dapat dilihat bahwa motivasi belajar kelompok kontrol tidak menunjukkan peningkatan yang signifikan setelah proses pembelajaran tanpa keterampilan membuka pelajaran. Hasil pretest menunjukkan bahwa dari 15 siswa, 13 siswa $(86,7 \%)$ berada dalam kategori cukup dan 2 siswa $(13,3 \%)$ berada dalam kategori rendah. Tidak ada siswa yang berada pada kategori tinggi atau sangat tinggi. Demikian pula pada hasil posttest yang menunjukkan 15 siswa, 13 siswa $(86,7 \%)$ berada dalam kategori cukup dan 2 siswa $(13,3 \%)$ berada dalam kategori rendah. Tidak ada siswa yang berada pada kategori tinggi atau sangat tinggi. Hasil tersebut menunjukkan bahwa tidak terjadi peningkatan motivasi belajar pada kelompok kontrol yang pembelajarannya tidak diberi perlakuan yaitu tanpa keterampilan membuka pelajaran.

5. Pengaruh keterampilan membuka pelajaran terhadap motivasi belajar siswa dalam pembelajaran Bahasa Indonesia di SDN 139 Inpres Lambatorang

Pengujian hipotesis data motivasi belajar Bahasa Indonesia diperoleh dari nilai gainscore. Analisis statistik gainscore dapat dilihat pada Tabel 4.5 berikut:

Tabel 4.5 Hasil Uji Gainscore pada Independet Samples T-Test

Group Statistics

\begin{tabular}{|ll|r|r|r|r|}
\hline & Grup & $\mathrm{N}$ & \multicolumn{1}{c|}{ Mean } & \multicolumn{1}{c|}{$\begin{array}{c}\text { Std. } \\
\text { Deviation }\end{array}$} & $\begin{array}{c}\text { Std. Error } \\
\text { Mean }\end{array}$ \\
\hline Gain & Kontrol & 15 & 3.2000 & 1.97122 & .50897 \\
& Eksperimen & 15 & 54.2667 & 9.62487 & 2.48513 \\
\hline
\end{tabular}

Independent Samples T-Test

\begin{tabular}{|c|c|c|c|c|c|c|c|c|c|c|}
\hline & \multicolumn{2}{|c|}{$\begin{array}{l}\text { Levene's } \\
\text { Test for } \\
\text { Equality of } \\
\text { Variances }\end{array}$} & \multicolumn{7}{|c|}{ t-test for Equality of Means } \\
\hline & & \multirow[b]{2}{*}{$\mathrm{F}$} & \multirow[b]{2}{*}{ Sig. } & \multirow[b]{2}{*}{$\mathrm{t}$} & \multirow[b]{2}{*}{ Df } & \multirow[b]{2}{*}{$\begin{array}{l}\text { Sig. (2- } \\
\text { tailed) }\end{array}$} & \multirow[b]{2}{*}{$\begin{array}{c}\text { Mean } \\
\text { Difference }\end{array}$} & \multirow[b]{2}{*}{$\begin{array}{l}\text { Std. Error } \\
\text { Difference }\end{array}$} & \multicolumn{2}{|c|}{$\begin{array}{c}95 \% \\
\text { Confidence } \\
\text { Interval of the } \\
\text { Difference }\end{array}$} \\
\hline & & & & & & & & & Lower & Upper \\
\hline \multirow[t]{2}{*}{ Gain } & $\begin{array}{l}\text { Equal } \\
\text { variances } \\
\text { assumed }\end{array}$ & 18.915 & .000 & -20.131 & 28 & .000 & -51.06667 & 2.53671 & -56.262 & -45.870 \\
\hline & $\begin{array}{l}\text { Equal } \\
\text { variances not } \\
\text { assumed }\end{array}$ & & & -20.131 & 15.172 & .000 & -51.06667 & 2.53671 & \begin{tabular}{|l|}
-56.468 \\
\end{tabular} & -45.665 \\
\hline
\end{tabular}

Nilai $\mathrm{t}_{\text {hitung }}$ yang diperoleh adalah 20.131. Nilai didistribusikan dengan $\alpha=0,05$ dan derajat kebebasan $(\mathrm{dk}=15-2=13)$. Nilai $\alpha$ dibagi 2 menjadi 0,025 sehingga diperoleh $t_{\text {tabel }}$ pada uji dua pihak yaitu 2,650. Dengan demikian diperoleh hasil $t_{\text {hitung }}>$ dari $t_{\text {tabel }}$ yakni $20.131>$ 2,650 yang berarti $\mathrm{H}_{0}$ ditolak. Dengan demikian dapat dikemukakan bahwa ada pengaruh keterampilan membuka pelajaran terhadap motivasi belajar siswa dalam pembelajaran Bahasa Indonesia siswa SDN 139 Inpres Lambatorang Kecamatan Bantimurung Kabupaten Maros dimana siswa yang diajar 
dengan memakai keterampilan membuka pelajaran motivasi belajarnya lebih tinggi.

\section{Pembahasan}

Keterampilan membuka pelajaran yang memuat apersepsi, menimbulkan motivasi, dan memberi acuan mampu menarik perhatian siswa untuk belajar. Kesiapan siswa yang dibangun di awal pembelajaran tentunya akan membantu siswa dalam mengikuti proses pembelajaran. Siswa lebih termotivasi untuk mempelajari materi-materi yang disajikan. Siswa belajar dengan perasaan senang yang mendorong siswa untuk terus aktif dalam mengikuti kegiatan pembelajaran, baik tanya jawab maupun mengerjakan tugas. Yunia (2014) mengemukakan bahwa kegiatan membuka pelajaran dapat membantu guru dalam mengkondisikan siswa untuk siap belajar. Siswa yang siap untuk belajar lebih aktif dalam pembelajaran dan termotivasi untuk mengikuti setiap tahapan pembelajaran.

Perbedaan kegiatan awal yang dilakukan pada kelompok eksperimen dan kelompok kontrol berpengaruh terhadap motivasi siswa dalam mengikuti pelajaran. Kelompok eksperimen yang diajar dengan menggunakan keterampilan membuka pelajaran lebih memiliki kesiapan mental dalam mengikuti rangkaian pembelajaran dari awal hingga akhir. Siswa lebih termotivasi sehingga mendorong siswa untuk aktif dalam pembelajaran. Sebaliknya pada kelompok kontrol yang tidak menggunakan keterampilan membuka pelajaran, siswa kurang aktif dalam pembelajaran. Siswa kurang merespon materi yang diberikan karena guru tidak membangun kesiapan mental siswa sebelum inti pelajaran dimulai. Hasil penelitian Yulianis (2014) menunjukkan bahwa ada perbedaan motivasi belajar antara siswa yang diajar dengan keterampilan membuka dan menutup pelajaran dengan siswa yang belajar tanpa keterampilan membuka dan menutup pelajaran dimana siswa yang diajar dengan keterampilan membuka dan menutup pelajaran memiliki motivasi belajar yang lebih tinggi.

Perbedaan perlakuan pada kelompok eksperimen dan kelompok kontrol tentunya akan berdampak pada motivasi belajar siswa. Berdasarkan data yang diperoleh dari pretest dan posttest, yang analisis secara deskriptif dan inferensial, menunjukkan motivasi belajar siswa pada kelompok eksperimen lebih tinggi daripada siswa pada kelompok kontrol. Data yang diperoleh menunjukkan rata-rata nilai kelompok eksperimen dan kelompok kontrol berbeda secara signifikan. Siswa yang diajar dengan keterampilan membuka pelajaran memiliki motivasi yang lebih tinggi dalam belajar karena ketertarikan mereka dimunculkan sebelum pembelajaran inti dimulai. Hal ini senada dengan pendapat yang dikemukakan Abimanyu (2008) bahwa motivasi dapat ditimbulkan melalui prosedur membuka pelajaran dengan memperhatikan hal-hal yang menarik perhatian siswa. Dengan demikian keterampilan membuka pelajaran penting untuk diterapkan agar siswa termotivasi dalam mengikuti proses pembelajaran.

\section{SIMPULAN DAN SARAN}

Berdasarkan hasil penelitian yang diperoleh, maka disimpulkan bahwa:

1. Aktivitas guru dalam pembelajaran Bahasa Indonesia pada pertemuan pertama dan kedua berada pada kategori tinggi. Pada pertemuan ketiga, keempat dan kelima berada pada kategori sangat tinggi.

2. Aktivitas siswa dalam pembelajaran Bahasa Indonesia dengan menggunakan keterampilan membuka pelajaran pada pertemuan pertama berada pada kategori cukup. Pada pertemuan kedua aktivitas siswa berada pada kategori tinggi, pada pertemuan ketiga, keempat dan kelima aktivitas siswa berada pada kategori sangat tinggi.

3. Motivasi belajar siswa sebelum dan sesudah diberi keterampilan membuka pelajaran pada kelompok eksperimen mengalami peningkatan dari kategori rendah dan cukup pada pretest menjadi kategori tinggi dan sangat tinggi pada posttest.

4. Motivasi belajar siswa dalam pembelajaran Bahasa Indonesia sebelum dan sesudah diberi pembelajaran tanpa kegiatan membuka pelajaran tidak mengalami peningkatan. Hasil yang diperoleh menunjukkan motivasi belajar siswa pada pretest dan posttest berada pada kategori yang sama yaitu kategori rendah dan cukup.

5. Keterampilan membuka pelajaran berpengaruh positif terhadap motivasi belajar siswa dalam pembelajaran Bahasa Indonesia 
siswa SDN 139 Inpres Lambatorang Kecamatan Bantimurung Kabupaten Maros.

Berdasarkan dari hasil penelitian, maka beberapa saran penulis ditujukan kepada:

1. Bagi Kepala Sekolah, hendaknya berusaha memfasilitasi pengembangan keterampilan mengajar guru khususnya keterampilan membuka pelajaran.

2. Bagi guru, hendaknya menerapkan prosedur membuka pelajaran dalam melaksanakan kegiatan pembelajaran di kelas.

3. Bagi peneliti lainnya, hendaknya dapat mengkaji lebih lanjut tentang pengaruh keterampilan membuka pelajaran terhadap motivasi belajar.

\section{DAFTAR RUJUKAN}

Abimanyu, Soli. 2008. Pengajaran Mikro. Makassar: Badan Penerbit UNM.

Hadis, Abdul dan Nurhayati. 2014. Psikologi dalam Pendidikan. Bandung: Alfabeta.

Khairani, Makmun. 2014. Psikologi Belajar. Yogyakarta: Aswaja Pressindo.

Majid, Abdul. 2010. Strategi Pembelajaran. Bandung: Remaja Rosdakarya.

Nashar, H. 2004. Peranan Motivasi \& Kemampuan Awal. Jakarta: Delia Press.

Nevid, J. 2013. Psychology: Concepts and applications. Belmont, CA: Wadworth.

Rusman. 2011. Mengembangkan Profesionalisme Guru. Jakarta: Rajawali Press.

Sardiman. 2007. Interaksi \& Motivasi Belajar Mengajar. Jakarta: Raja Grafindo Persada.

Usman, Moh. Uzer. 2008. Menjadi Guru Professional. Bandung: Remaja Rosdakarya.

Yunia, Meta. 2014. Pengaruh Keterampilan Membuka dan Menutup Pelajaran terhadap Motivasi Belajar Siswa SD Negeri Jatibarang Kidul 05 Kabupaten Brebes. Skripsi. Tidak diterbitkan. Semarang: Universitas Negeri Semarang.

Yulianis, Nurma. 2014. Hubungan Keterampilan Membuka dan Menutup Pembelajaran dengan Motivasi Belajar Siswa Kelas V SD Negeri 45 Kota Bengkulu. Tesis. Tidak diterbitkan. Bengkulu: Universitas Bengkulu. 